\title{
肝細胞癌に対する肝部分切除術に打ける問題点，とくに 術後肝不全と根治性に関する検討
}

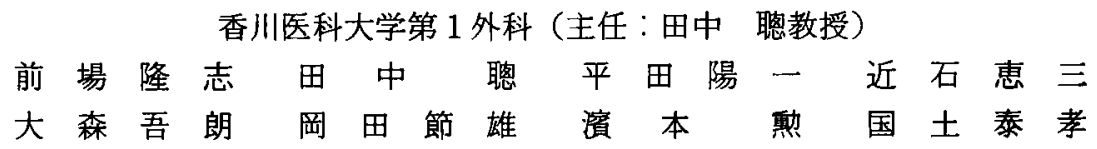

肝細胞癌に対して肝部分切除術が施行された15例の治療上の問題点につき検討した。 全例が肝硬变を合併し，その中でも食道静脈瘤を合併していた 8 例では，非合併例に比 へ ICG-R $\mathrm{R}_{15}$, OGTT linearity index, 血小板数に有意の低下を認め, 術後 1 力月を経過 しても肝機能障害の遷延が明らかであった。肝切除とともに食道静脈瘤直達手術を 5 例 に実施したが，うち 3 例が術後肝不全を併発した。解剖学的制約から15中例 4 例が TW 陽性による非治㾤切除例となった．以上より残存肝予備能の面から肝部分切除術を選択 せざるを得ない症例には，食道静脈㿔直達手術の一期的附加は過大な手術侵襲を与克る ものと考之られ，術前の内視鏡的硬化療法を第一選択とすべきである。高た，断端再発 対策が必要であり，われわれは術後の予防的門脈内注入癌化学療法によって治療成績の 向上を図っている。

索引用語: 肝細胞癌, 食道静脈瘤, 肝部分切除術, 内視鏡的硬化療法, 門脈内癌化学療法

\section{はじめに}

肝細胞癌は，高率に肝硬変を合併して括り，その外 科治療面においては，相反する2つの条件，すなわち 根治性と残存肝予備能力とを満足すべき手術術式の選 択が必要である。このらちとくに，肝亜区域切除術や 肝部分切除術など縮小手術の適応とせざるる得ない訮 細胞癌症例は, 高度の肝硬变を合併する場合が大部分 であるため, 術中の過大侵襲や, 術後合併症の併発に より，容易に肝不全状態へと移行し，た之之肝不全死 は免れたとしても，满足すべき quality of lifeが得ら れない場合も多い。

教室における過去 5 年間の肝細胞癌切除症例のうち 肝部分切除術を施行した症例について, 術後肝不全と 癌根治性の問題点について臨床的に検討を試みた。

\section{方法およひ結果}

\section{1. 対象およU背景因子}

教室で1983年10月から1988年 8 月までに肝切除術を 施行した症例は77例で, 対象疾患が肝細胞癌であった むのは29例であった。このうちで肝部分切除術の適応 とされた症例は17例であったが，今回は再発再切除の

1989年 1 月 6 日受付 1989 年 7 月 3 日採用
2 例を除いた15例を対象として検討した，15症例のう ち男性は11例, 女性は 4 例で, 年龄は45歳から78歳, 平均62.6歳であった。肝硬変は組織学的に全例に合併 して扣り，肝癌取扱い規約 ${ }^{11}$ 上の $z_{1}: 3$ 例, $z_{2}: 5$ 例, $z_{3}: 7$ 例と $z_{2}$ 以上の肝硬变合併例が $80 \%$ を占めてい た. 食道静脈瘤は 8 例，53\%に合併し，脾機能立進症 は12例，80\%に合併していた（表 1 ).

\section{2. 術前肝機能とその術後推移}

教室で肝予備能の指標として用いている術前検查値 の5ち ICG-R $\mathrm{R}_{15}$, 血清総ビリルビン（T. Bil），血清フ ルブミン (Alb)， ヘパプラスチン(HPT) の術前値を, 肝部分切除例とそれ以上の区域切除例とで比較する と, ICG-R 15 と HPT が肝部分切除例で有意に劣ってい た(図 1 )。 。た, GOT, T-Bil, HPT，血小板数の術 後の推移を比較すると, いずれの検查值る術後 3 日目 まで悪化傾向を示したが，術後 2 週間でほぼ術前值に 回復する傾向がみられた。なお血小板数は，術前・術 後を通じて肝部分切除例で有意の低值を示したが，こ れは肝部分切除例で脾機能六進症の合併が $80 \%$ と高率 であったためと考えられる(图 2 )。術前 ICG-R $\mathbf{R}_{15}$ と術 後 1 カ月目の肝機能 score との関係をみると, 両者の 間に明らかな相関珄が認められ，術前 ICG 值が不良な 
表 1 肝細胞癌に対す万肝部分切除症例

\begin{tabular}{|c|c|c|c|c|c|c|c|c|}
\hline 症例 & 年齿・性 & 併存肝硬变 & $\mathrm{EV}$ 合併 & HS 合併 & 術前治療 & 附加手術 & 術後合併症 & 遠隔成績 \\
\hline 1 & $50 \cdot \mathrm{M}$ & $\mathrm{Z}_{3}$ & $(+)$ & $(+)$ & (TAE & & EV 出血 & 7 力月肝癌死 \\
\hline 2 & $76 \cdot \mathrm{M}$ & $Z_{1}$ & $(-)$ & $(-)$ & & & & 30 力月生 \\
\hline 3 & $76 \cdot \mathrm{M}$ & $Z_{2}$ & $(-)$ & $(+)$ & & & & 29 力月生 \\
\hline 4 & $62 \cdot \mathrm{M}$ & $Z_{1}$ & $(-)$ & $(-)$ & & & 胆汁瘦 & 20 力月生 \\
\hline 5 & $69 \cdot \mathrm{F}$ & $Z_{2}$ & $(-)$ & $(-)$ & & PVC & & 16 力月生 \\
\hline 6 & $71 \cdot M$ & $Z_{3}$ & $(+)$ & $(+)$ & & Hassab & & 8 力月肝不全死 \\
\hline 7 & $62 \cdot \mathrm{M}$ & $Z_{3}$ & $(+)$ & $(+)$ & TAE & (胃上部切 & 肝不全 & 8 力月肝不全死 \\
\hline 8 & $65 \cdot F$ & $Z_{2}$ & $(-)$ & $(+)$ & & & & 10力月生 \\
\hline 9 & $78 \cdot \mathrm{M}$ & $Z_{1}$ & $(-)$ & $(t)$ & & & & 8 力月生 \\
\hline 10 & $63 \cdot \mathrm{M}$ & $\mathrm{Z}_{2}$ & $(+)$ & $(t)$ & & PVC & & 8 力月生 \\
\hline 11 & $55 \cdot M$ & $Z_{2}$ & $(-)$ & $(+)$ & & & & 6 力月生 \\
\hline 12 & $45 \cdot M$ & $Z_{3}$ & $(+)$ & $(+)$ & PSE & $\left(\begin{array}{c}\text { Hassab } \\
\text { - PVC }\end{array}\right.$ & & 5 力月生 \\
\hline 13 & $60 \cdot F$ & $Z_{3}$ & $(+)$ & $(+)$ & & PVC & & 4 力月生 \\
\hline 14 & $60 \cdot M$ & $Z_{3}$ & $(+)$ & $(+)$ & TAE & (Hassab & & 3 力月生 \\
\hline 15 & $57 \cdot F$ & $Z_{3}$ & $(+)$ & $(+)$ & & $\left(\begin{array}{c}\text { Hassab } \\
\cdot \text { PVC }\end{array}\right.$ & 肝不全 & 2 力月生 \\
\hline
\end{tabular}

EV : 食道静脈瘤, HS : 脾機能穴進症, TAE : 肝動脈塞栓術, Sclero：内視鏡的硬化療法, PSE : 脾部分塞栓術, PVC : 限脈カニュレーション
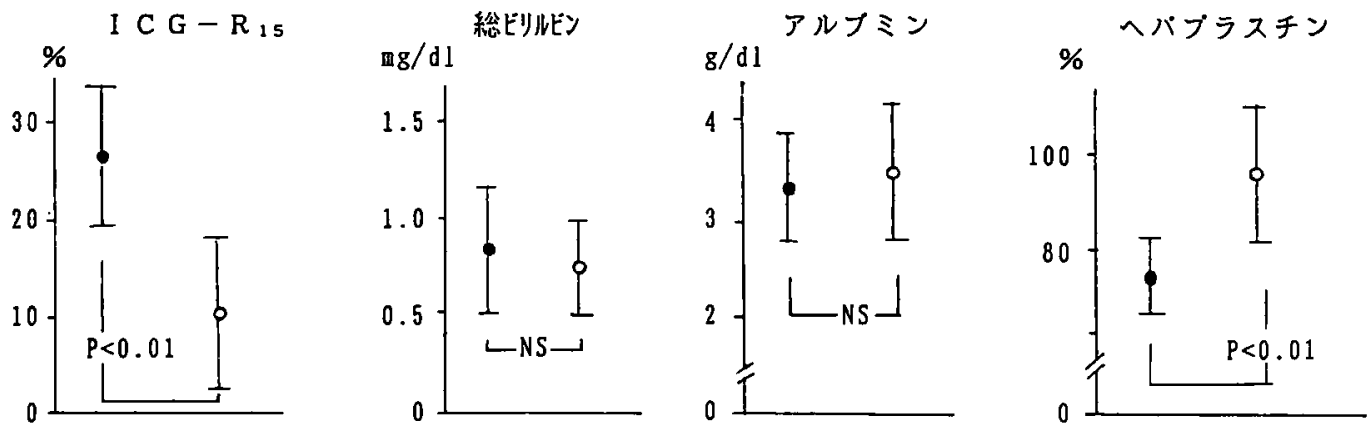

$$
\left(\begin{array}{l}
\cdot \text { 肝部分切除例 } \quad(n=15) \\
0 \text { 一区域以上盰切除例 } \quad(n=50)
\end{array}\right.
$$

図 1 切除範囲からみた術前肝機能

ほど肝機能障害が術後長期にわたって遷延する傾向が 示された（図 3).

\section{3. 術前療法ならひに合併手術およひ処置}

術前肝動脈塞栓術（TAE）を 3 例に行った。 また高 度の脾機能六進症合併の 1 例に対し, 術前脾部分塞栓 術を, 食道静脈瘤合併の5ちの 1 例に内視鏡的硬化療
法を施行した。肝部分切除とともに Hassab 手術 4 例, 胃上部切除術 1 例を併施し，6例に皮下埋没式門脈内 カニューレを留置した（表1).

4. 切除標本所見（表 2 ）

肝細胞癌の主占拠部位は segment 8 K 6 例とやや多 い傾向がみられた。腫海数は単発13例，多発 2 例で, 

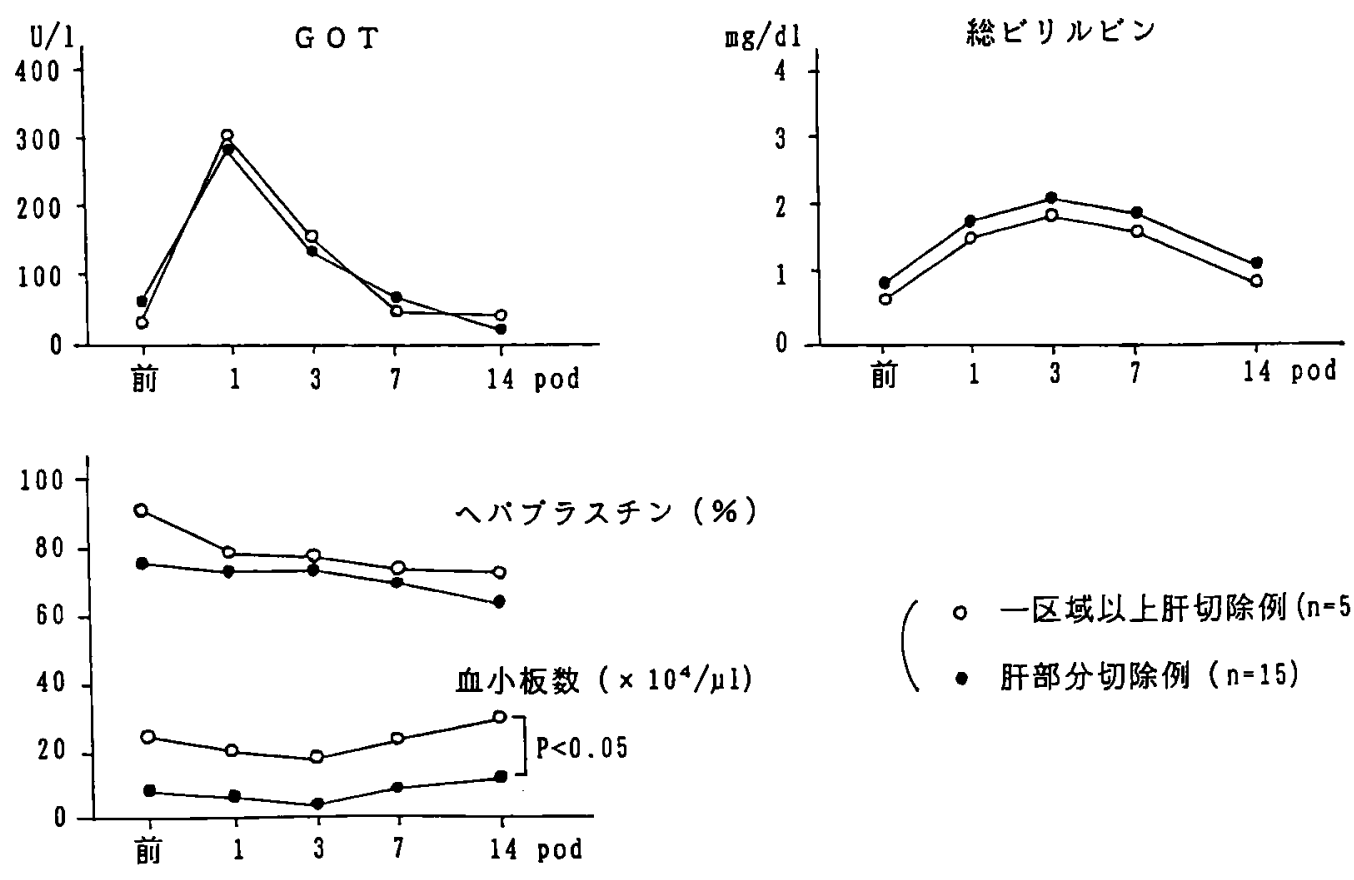

図 2 切除範囲からみた険査值の術後推移

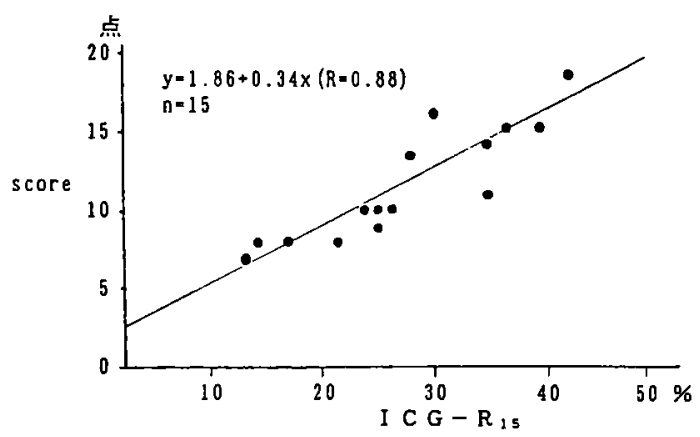

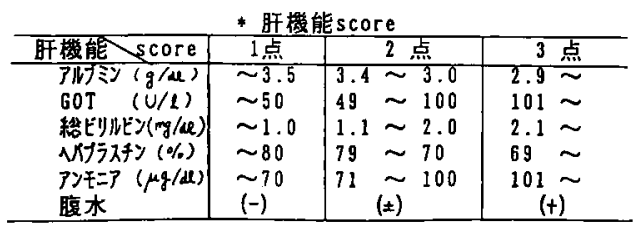

図 3 肝部分切除例の術前 ICG 值と術後 1 カ月にお ける肝機能 score との相関

その最大腫湯径は，2cm 未满の small liver cancer が

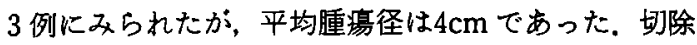
標本上での肝切離面癌浸潤（tw）因子をみると15例中 4 例が $\mathrm{tw}$ 陽性の非治痖切除例となった。

\section{5. 術後合併症と術後経過}

手術死亡例はなかったが, 術後肝不全は急性期に2 例みられた。いずれも術直後から T.Bil の著明な上昇 (20mg/dl 以上)を示したが，血浆吸着療法の併用によ り急性期を離脱することが可能となった。

遠隔成績では， 1 例が術後 7 カ月て癌再発死， 2 例 が術後 8 力月で肝不全死した。また腫瘍が 3 個存在し た症例 8 は, 術後 4 カ月で肝内再発をみ, TAEにより 経過観察中である。その他の症例は現在まで再発徽候 を認めていない(表 1)。術後急性期および遠隔期に肝 不全を来たした 3 症例について，その誘因と考兄られ る risk factor を表 3 に示した。肝機能検査上, 症例 7 で ICG-R $\mathrm{R}_{15}$ と T. Bil の術前值が，他の部分切除症例と の間に有意差を認めた。 3 症例ともに高度の食道静脈 瘤を合併しており，これに対して肝切除と同時に静脈 瘤手術を併施して扣り，術中出血量も多量となってい た。

図 4 に食道静脈溜を合併した 8 例についての術前術 後の検查値を，非合併例 7 例と比較し示した。 これに よると，ICG- $R_{15}$, OGTT linearity index，血小板数 の術前値において食道静脈瘤合併例に有意の低下がみ られた。また，術後1カ月に括ける肝機能 scoreをみて む，食道静脈瘤合併例に拈いて明らかな回復遅延を認 
表 2 病理組織学的所見

\begin{tabular}{r|c|c|l|c|c}
\hline 症例 & 占拠部位 & 睡瘍数 & \multicolumn{1}{|c|}{ 畽 癃 径 $(\mathrm{cm})$} & Edmondson 分類 & tw \\
\hline 1 & $\mathrm{~S}-8$ & 1 & $4.5 \times 4$ & II & $(+)$ \\
2 & 7 & 1 & $5.7 \times 5$ & II & $(-)$ \\
3 & 4 & 1 & $5 \times 5$ & 不明 & $(+)$ \\
4 & 5 & 1 & $3 \times 3$ & I & $(-)$ \\
5 & 6 & 1 & $2 \times 1.8$ & II & $(-)$ \\
6 & 8 & 1 & $1.9 \times 1.9$ & II & $(-)$ \\
7 & 5 & 1 & $1.5 \times 1.5$ & 不明 & $(-)$ \\
8 & 8 & 3 & $2.5 \times 2.2,1.7 \times 1.5,1.2 \times 1$ & II & $(-)$ \\
9 & 6 & 1 & $3 \times 3$ & III & $(-)$ \\
10 & 5 & 1 & $1.9 \times 1.8$ & II & $(+)$ \\
11 & 7 & 1 & $4 \times 3.7$ & II & $(+)$ \\
12 & 4 & 1 & $5.1 \times 4$ & II & $(-)$ \\
13 & 8 & 2 & $1.7 \times 1.3,1.6 \times 1.4$ & I, II & $(-)$ \\
14 & 8 & 1 & $3.5 \times 3.5$ & II & $(-)$ \\
15 & 8 & 1 & $4 \times 4$ & II & $(-)$ \\
\hline
\end{tabular}

表 3 術後肝不全発生例における術前・術中 risk factor

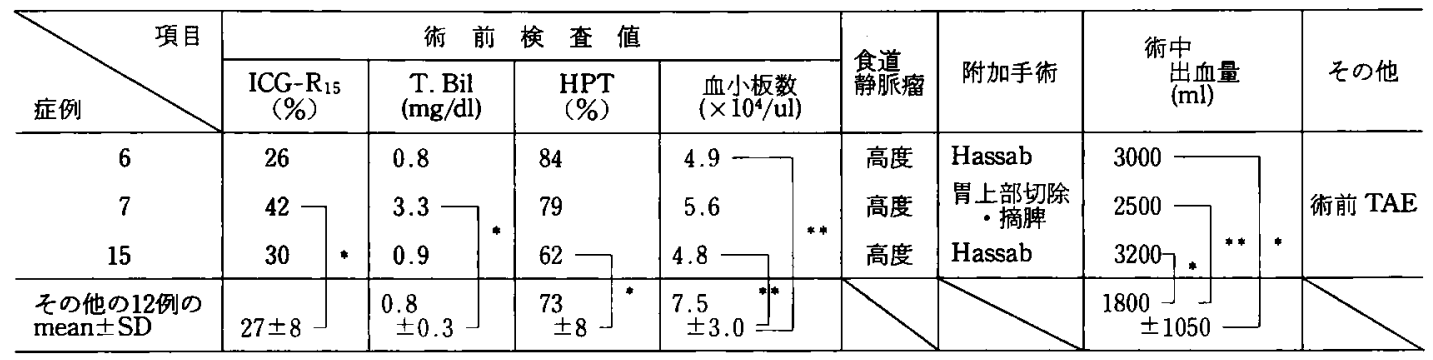

$* \mathrm{p}<0.01$

${ }^{* *} \mathrm{p}<0.05$

あた。

\section{考案}

肝細胞癌に対する肝切除術は，最近の牫存肝予備能 力の術前評価法 ${ }^{2)-4)}$ の確立によって, 術後肝不全に代 表される致命的な術後合併症は極めて減少し，安全な 手術手技の一つとなってきた。現在の肝切除術に対す る残存肝予備能力の術前評価法は，多数例の肝切除経 験から得られた複数の肝指標をもとに切除許容範囲を 決定したものが大部分であり，多くの施設が，これら の適応基準に従って肝切除術を行っているのが現状で あろ5。当科で肝予備能評価から，肝部分切除術が選 択された症例では，病理組織所見から $z_{2} ， z_{3}$ に相当す る中等度以上の肝硬変合併例が 15 例中 12 例, $80 \%$ に られたにもかかわらず,肝機能検査値の術後推移には， 肝予備能が比較的良好と考えられる一区域以上の肝切 除症例との間に有意差はみられず，高度の肝硬変合併 例であっても，適切な肝切除範囲である限り充分耐術
しらるものと考えられる。

肝細胞癌の外科治療上において制約を受ける因子に 食道静脈瘤の合併がある。第 8 回全国肝癌追跡調査報 告5)によると，肝細胞癌の $42.4 \% か ゙$ 食道静脈瘤を合併 して拈り，その予後を左右する大きな要因の一つとさ れている，最近では，高度の肝硬変合併例に対しても 積極的に肝切除術がなされるよらになり，併存する食 道静脈瘤に対しても，一期的な食道静脈瘤附加手術を 行ならべきであるとの意見(7)もあるが，肝部分切除術 が選択される症例では，一般に肝予備能力は極めて之 しいことが多く，静脈瘤手術の附加に伴う手術侵警は 予想以上に過大となる場合もあり，その手術適応にあ たっては充分な配慮が必要である，当科の症例では， 術後急性期に 2 例，遠隔期に 1 例の肝不全が発生した が，いずれす合併する高度の食道静脈瘤に対して，一 期的に静脈瘤手術が併施されていた。この手術侵襲が 肝不全発生の誘因か丕かの判定は困難ではあるが，食 


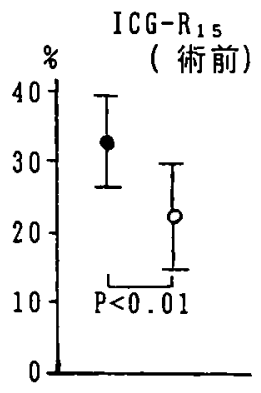

白血球数

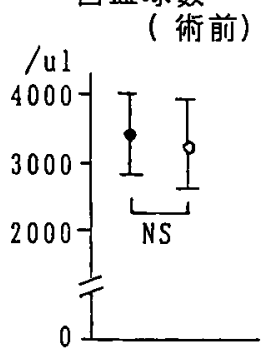

OGTT

linearity index

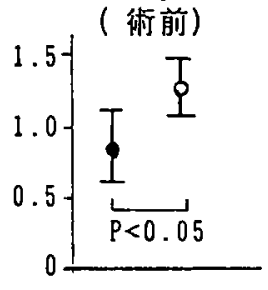

血小板数

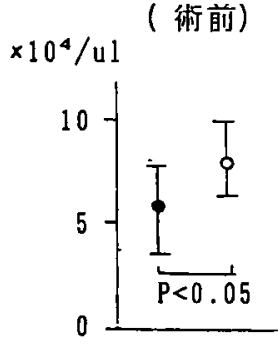

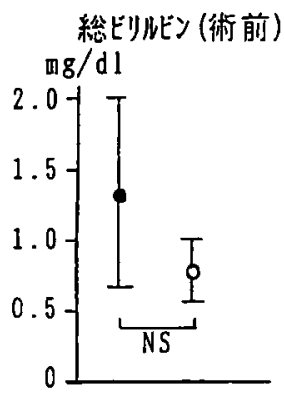

䀒機能score (術後1加月)

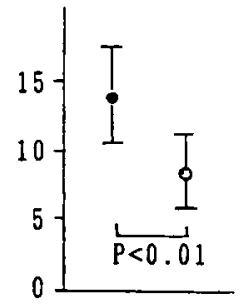

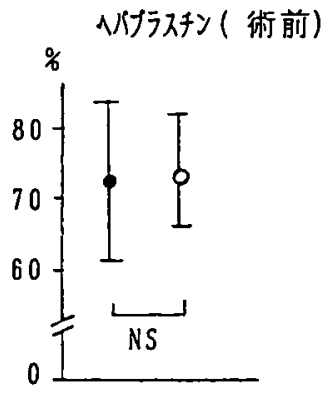

- 合併例 $(n=8)$

○非合併例 $(n=7)$

图 4 食道静脈嘴合阱の有無からみた模査値の差

道静脈瘤合併例の術前検査値をみると, ICG- $R_{15}$ と血 小板数において非合併例との間に有意差を認め, 術後 1 カ月目における肝機能む不良で, 手術による肝機能 障害は術後長期間にわたって遷延化する傾向が認めら れた．すなわち，三條ら名も指摘しているように，食道 静脈瘤を合併する症例では, 肝硬変の中で最も肝予備 能力が低下しており，大部分がすでに代償不全期に 宿った病態であると考えられ，このよらな症例に対し 一期的に静脈瘤手術を附加することは，いたずらに手 街侵襲を大きくするのみで，果たして長期的予後の改 善が得られるかに関しては薙問である。飯田らのは，食 道静脈瘤合併肝癌に対する肝葉切除では，切除後に門 脈王上昇がみられ，食道静脈瘤破裂の危険性が高くな るため，食道離断術の附加が必要であるとしている。 また, 兼松ら ${ }^{10}$ は, 肝葉切除が可能な程度の肝予備能力 を有する症例で, 肝切除範囲が広範でないるのに限り 静脈瘤附加手術を併施するとしている。これらの報告 は, いずれも肝予備能力が比較的良好で肝葉切除が可 能な症例に対しての手術適応と考えられ，肝予備能力 の低下のために肝部分切除が選択されるような症例で は, 三條ら ${ }^{81}$ ，岩崎ら ${ }^{111}$ ，牧野ら ${ }^{12)}$ 指摘しているよう に, 静脈瘤手術の一期的併施は肝硬変の natural history を悪化させることはあっても改善の方向に向か うことはないと考えるべきであり，われわれの 3 症例
の術後経過はこのことを支持している. 従って，この ような症例に合併する食道静脈瘤に対しては, より侵 㜔の少ない治療法，とくに術前内視鏡的硬化療法を選 択すべきであると思われる，本法は肝機能が高度に障 害されている症例に対しても，非侵襲的で安全な手技 とされているが，直達手術に比へ，その再発率が高い 点が問題となっている ${ }^{13)}$. しかし, 少なくとも肝切除後 の急性期における静脈瘤破裂に対する予防効果とい5 点では, 術前硬化療法で充分に対処し得ると考えられ る.

全国肝癌追跡調查報告5)によると, 全肝切除例の5 ち31.3\%が TW 陽性に終っているが, 肝部分切除術で は縮小手術であるがためにその頻度は高く，とくに肝 静脈や門脈本幹に隣接する腫掦では，その解剖学的な 制約から，充分なる切除縁を得られない場合も多い。 われわれの症例でも，このような理由から15例中 4 例 に tw 陽性症例があり，亏ち 2 例に術後 4 カ月と 7 カ 月に局所再発が認められている. 残存肝機能上の制約 から部分切除とせざるを得ない症例においては，常に 肝内局所再発の危険性が高いことを考省ておく必要が

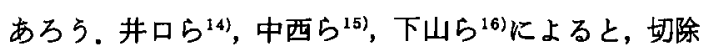
範囲や TW 因子と再発との間には一定傾向はないと する報告む多いが，彼らも縮小手術に括ける再発予防 策としての補助寮法の必要性を強調しており,この点, 
山本ら ${ }^{17}$ は, 局所再発予防対策としての衍前 TAEゃ 術後の植之込及型動注ポートに上る間欠的動注化学療 法の有用性を報告している。われわれる最近の肝部分 切除症例には原則として皮下埋没式門脈ポートを留置 し，術後より予防的癌化学療法を併用している，広橋 らは $0.5 \mathrm{~cm}$ 末満の小肝癌や娘結節では門脈血の支配 が優位であったと述べて扰り ${ }^{18)}$ ，肉眼的に腫瘍を切除 し得た症例の再発予防といら観点では肝動脈よりは門 脈内投与法が有効であろらといら理由から，現在われ われは門脈内癌化学療法を選択しているが，いまだ観 察期間が短くその有效性については評価し得ない．ま た，併存する肝硬变に対する化学療法剤の与兄る肝細 胞障害性 ${ }^{19}$ も否定し得ず, この点に関しても今後の検 討が必要と考えられる。

\section{結 語}

肝予備能が不充分であるがために肝部分切除術を選 択した肝細胞癌15例について，術後肝不全の発生と癌 根治性に関する検討を加えた。とくに食道静脈瘤合併 症例では, 直達手術の附加など肝切除以外の手術侵裂 は避け，術前の内視鏡的硬化療法を第一選択とすべき であることと，肝部分切除に伴う解剖学的制約からの 根治性低下に対する対策が不可欠であり，その一法と してわ机われは皮下りザーバー付門脈カニニレーショ ソによる予防的門脈内癌化学療法を行っていることを 述べた。

\section{文献}

1）日本肝癌研究会：原発性肝癌取扱い規約, 金原出 版, 東京, 1987

2）水本龍二, 野口 孝：肝硬变合併肝癌の手術，外科 $40: 1401-1406,1978$

3）山中若樹, 岡本英三：重回㷌分析を用いた肝切除 の適応判定, 日外会誌 $84: 908-911,1983$

4）高崎 健：肝硬变併存肝癌の切除術式の選択基準 一安全性，根治性を考慮に入れた切除範围の調節 とそれに必要な手術手技の工夫一，日消外会誌 $19: 1881-1889,1986$

5）日本肝癌研究会：第 8 回全国原発性肝癌追跡調查 報告書, 1988
6）二川俊二，奥山耕一，児島邦明他：食道静脈瘤合併 肝癌の治療, 臨成人病 $15: 35-40,1985$

7) 河合庸化, 山本貞博, 竹重言人他：肝細胞癌の予後 からみた治療法の評価，日消外会誌 $21 ： 1248$ $-1252,1988$

8）三條建昌, 出月康夫：肝細胞癌一治療法の進步・食 道静脈瘤合併例の対策, 龟田治男編, 消化器病七 ミナー26, へるす出版, 東京, 1987, p166-179

9）飯田修平, 都築俊治：肝癌合併患者の治療・食道静 脈瘤治療の実際, 出月康夫 編, 医学書院, 東京, 1985, p259-265

10）兼松隆之, 井口 㸷：食道静脈瘤併存肝癌に対寸 る治療，日外会誌 $84: 923-926,1983$

11）岩崎洋治：食道静脈瘤を伴なら肝細胞癌の治療, 消化器外科セミナー 17 , へるす出版, 東京, 1985 , p286-302

12）牧野弘之, 弘中 武, 園山輝久他：食道静脈癐併存 肝細胞癌における肝切除術前後の静脈瘤变化捛よ び出血予知比関する検討，日消外会誌 $21 ： 2121$ $-2126,1988$

13）高瀬靖広，泾谷 進，近森文夫他：食道静脈瘤に対 する硬化療法一通応と手技, 消化器外科 $11: 291$ $-296,1988$

14）井口 潔, 兼松陡之：硬变合併所癌に対する縮小 手㭪と適応，消外 $6: 1713-1717,1983$

15）中西昌美，佐野秀一，葛西洋一：原発性肝癌維小手 術の適応と意義，癌の臨 $30: 1087-1091,1984$

16）下山孝陖, 福田 豊, 原田達郎他：肝硬变併存肝癌 飞対する外科的治療の問題点，日消外会誌 19 ： 1942-1951, 1986

17）山本雅一, 高崎 健: 肝細胞癌再発例の治療, 消外 $11: 613-618,1988$

18）広橋一裕, 酒井克治, 木下博明他：肝動脈塞栓療法 後肝切除施行肝細胞癌症例の臨床的ならびに病理 組織学的研究，日外会誌 $86: 555-565,1985$

19）高橋 修, 宮崎 勝, 志村賢範：肝切除後の残存肝 に対する肝動脈塞栓術および制癌剤肝動脈注入療 法の安全性に関するラットに拈ける実験的検討， 日消外会誌 $21: 2388-2393,1988$ 


\section{PROBLEMS OF PARTIAL HEPATECTOMY FOR HEPATOCELLULAR CARCINOMA, WITH A SPECIAL REFFERENCES TO POSTOPERATIVE HEPATIC FAILURE AND SURGICAL RADICALLITY}

Takashi MAEBA, Satoshi TANAKA, Yohichi HIRATA, Keizoh CHIKAISHI, Goroh OHMORI, Setsuo OKADA, Isao HAMAMOTO and Yasutaka KOKUDO

First Department of Surgery, Kagawa Medical School, Kagawa

Therapeutic problems in 15 patients with partially resected hepatocellular carcinomas were studied.

Significant differences in preoperative values of ICG- $R_{15}$, OGTT linearity index, serum platelet counts and postoperative score of hepatic function were noted between patients with and without esophageal varices. Three patients who underwent partial hepatectomies combined with non shunting operations for esophageal varices were complicated by postoperative hepatic failure. For the limitation of anatomical aspect, 4 patients were not curatively resected due to TW factor.

These results suggested that simultaneous surgical treatment for esophageal varices complicated with hepatocellular carcinoma should cause some damages to patients who were indicated partial hepatectomies, therefore preoperative endoscopic sclerotherapy should be first selected for these patients. For the local recurrence of partially resected hepatocellular carcinoma, propylactic portal infusion chemotherapy is considered to be a useful postoperative thrapy. 